\title{
Initial Steps towards Biocontrol in Hops: Successful Colonization and Plant Growth Promotion by Four Bacterial Biocontrol Agents
}

\section{Katja A. Maurer ${ }^{1, *}$, Christin Zachow ${ }^{2}$, Stefan Seefelder ${ }^{1}$ and Gabriele Berg ${ }^{3}$}

1 Bavarian State Research Centre for Agriculture, Institute for Crop Science and Plant Breeding, Hop Breeding Research and Genome Analysis, Am Gereuth 2, D-85354 Freising, Germany; E-Mail: stefan.seefelder@LfL.bayern.de

2 Austrian Centre of Industrial Biotechnology (ACIB GmbH), Petersgasse 14, A-8010 Graz, Austria; E-Mail: christin.zachow@tugraz.at

3 Graz University of Technology, Environmental Biotechnology, Petersgasse 12, A-8010 Graz, Austria; E-Mail: gabriele.berg@tugraz.at

* Author to whom correspondence should be addressed; E-Mail: katja.maurer@LfL.bayern.de; Tel.: +49-(0)8161-71-4817; Fax: +49-(0)8161-71-4514.

Received: 31 August 2013; in revised form: 11 September 2013 / Accepted: 12 September 2013 / Published: 26 September 2013

\begin{abstract}
Verticillium wilt, caused by Verticillium nonalfalfae and $V$. dahliae, is a devastating disease in hops that can cause considerable economic crop losses. The perennial use of hops combined with the long persistence of the pathogen in soil make it difficult to suppress the disease with conventional measures. Biological control agents (BCA) are the basis of an environmentally friendly plant protection strategy that uses plant promotion and antagonistic effects of microorganisms. We evaluated the effect of four selected beneficial bacterial strains, Burkholderia terricola ZR2-12, Pseudomonas poae RE*1-1-14, Serratia plymuthica 3Re4-18, and Stenotrophomonas rhizophila DSM14405 ${ }^{\mathrm{T}}$ for their use in hops. All strains were shown to be both rhizosphere and endorhiza competent, and their abundances ranged from $\log _{10} 3.0$ to $\log _{10} 6.2 \mathrm{CFU} \mathrm{g}$ goot fresh weight in the endorhiza and from $\log _{10} 2.9$ to $\log _{10} 4.7 \mathrm{CFU} \mathrm{g} \mathrm{g}^{-1}$ root fresh weight in the rhizosphere with $B$. terricola ZR2-12 showing the highest overall cell densities. Microscopic visualization of DsRed-labeled transformants with confocal laser scanning microscopy showed different colonization patterns and confirmed the rhizosphere competence. Growth promoting effects on seedlings treated with bacteria were found for
\end{abstract}


S. plymuthica 3Re4-18 and S. rhizophila DSM14405 ${ }^{\mathrm{T}}$. Competent colonization and plant growth promoting effects are the most important prerequisites towards efficient biocontrol.

Keywords: Humulus lupulus; beneficial bacteria; root colonization; growth promotion; biological control; Verticillium wilt

\section{Introduction}

Verticillium albo-atrum Reinke \& Berthold and $V$. dahliae Klebahn are devastating plant pathogens in many crop species [1] as Verticillium wilt is becoming a considerable threat in hops (Humulus lupulus L.). While first reported in England in 1924 [2], V. albo-atrum has since been divided and classified into two species according to Inderbitzin et al.: $V$. albo-atrum and the hop-infesting $V$. nonalfalfae [3]. $V$. nonalfalfae is the main pathogen of Verticillium wilt in hops that can cause devastating damage, and has been found in hop in Germany, Poland, Belgium, France, Slovenia, New Zealand, and the USA [4]. V. nonalfalfae is differentiated into fluctuating (mild) and progressive (lethal) pathotypes depending on the virulence of the isolates [5]. Plants infected with the lethal pathotypes, wither and often die, whereas hops infected with the mild pathotypes tolerate the disease.

Verticillium species are soil-borne pathogens, which are difficult to control with fungicides due to their ecological behavior. Resistant or tolerant hop cultivars and phytosanitary measures are the only current methods to prevent the wilt as hops are perennial crops and the fungus can survive for many years by producing resting structures. Hence, the hop infection by Verticillium spp. has major implications. An alternative and environmentally friendly strategy is biological control. In recent decades, many studies have proven the efficacy of biological control agents (BCAs) from the genera Pseudomonas and Serratia against Verticillium spp. in annual crops [6,7], but also for perennial crops such as olives [8]. In this way, the antagonistic bacteria inhibit plant pathogens via various mechanisms of disease suppression while the plant-associated microorganisms strengthen and promote plant growth $[9,10]$. Knowledge and understanding of these beneficial bacteria, their ability to colonize the roots, and their potential plant growth promoting (PGP) effects with pathogens interaction will help translate these properties into efficient biological control strategies [11]. Moreover, root competence was identified as a key prerequisite for successful biocontrol approaches [12].

An efficient BCA must be able to establish itself and survive in the root system. According to Weller, a root colonizer is defined as 'a bacterium that when introduced becomes distributed along the root in natural soil, propagates, and survives several weeks in the presence of competition from the indigenous rhizosphere microflora' [13]. Therefore, the first step towards an efficient biocontrol is to demonstrate the successful colonization in the root system of the plant. Afterwards, the bacterial treatment that could potentially strengthen the plants against diseases and/or stimulate the plant growth is analyzed. Several studies described successful biocontrol approaches towards $V$. dahliae for cotton, strawberry, olive, and oilseed rape [14-17], yet biocontrol against $V$. albo-atrum is rarely investigated. Talaromyces flavus was found as a fungal antagonist against $V$. albo-atrum in cucumber, potato, and tomato [18-20]. However, little is known to control Verticillium wilt in hops. 
The objective of this study was to take a first step into the biological control of hops. Therefore, we (i) evaluated the root competence of four previously selected beneficial bacterial strains. Furthermore, (ii) the colonization behavior of the selected, red fluorescent protein gene (DsRed) labeled bacteria was characterized with confocal laser scanning microscopy (CLSM), and (iii) potential PGP effects were determined by bacterial treatments of seedlings. Four plant-associated bacteria were selected: Burkholderia terricola ZR2-12 [21], Pseudomonas poae RE*1-1-14 (syn. P. trivialis) [22], Serratia plymuthica 3Re4-18 [23], and Stenotrophomonas rhizophila DSM14405 ${ }^{\mathrm{T}}(=\mathrm{e}-\mathrm{p} 10$ and $=$ P69) [24] due to their promising effects on targeted pathosystem and other plant beneficial properties [22,25-30]. For example, B. terricola ZR2-12 has proven to be an excellent root colonizer [21,31], and P. poae RE*1-1-14 was successfully applied in the sugar beet - Rhizoctonia solani pathosystem as reported by Zachow et al. [30]. The strain S. plymuthica 3Re4-18 was also described as a competent root colonizer and biocontrol agent in diverse crops [23,25,26,28,30,32]. The quorum-sensing-dependent antagonistic effect of $S$. plymuthica against $V$. dahliae was investigated in details [7]. Recently, the positive effect on plant growth and the strengthening of $S$. rhizophila DSM14405 ${ }^{\mathrm{T}}$ was supported $[29,33]$ and an indirect antifungal activity against soil-borne pathogens has been demonstrated [24].

\section{Results and Discussion}

\subsection{Rhizosphere and Endorhiza Competence by Measuring Bacterial Abundance}

The competence to colonize root systems was demonstrated via the re-isolation of rifampicin-resistant mutants of B. terricola ZR2-12, P. poae RE*1-1-14, S. plymuthica 3Re4-18, and S. rhizophila DSM $14405^{\mathrm{T}}$ from the rhizosphere and endorhiza of hops. Four weeks after inoculation, bacteria from the rhizosphere and endorhiza of roots were re-isolated on nutrient agar. In general, the rhizosphere was colonized from $\log _{10} 2.9$ to $\log _{10} 4.7 \mathrm{CFU} \mathrm{g^{-1 }}$ root fresh weight (RFW) and the bacterial abundance ranged from $\log _{10} 3.0$ to $\log _{10} 6.2 \mathrm{CFU} \mathrm{g}{ }^{-1} \mathrm{RFW}$ in the endorhiza (Figure 1). In this study, higher abundances were assessed for the bacteria in the endorhiza than in the rhizosphere of hop roots. B. terricola ZR2-12 showed the highest cell density $\left(\log _{10} 4.7 \pm 0.1 \mathrm{CFU} \mathrm{g}^{-1} \mathrm{RFW}\right.$ in the rhizosphere and $\log _{10} 6.2 \pm 0.4 \mathrm{CFU} \mathrm{g}^{-1} \mathrm{RFW}$ in the endorhiza), as the abundances were up to three orders of magnitudes greater than the cell numbers of the other bacteria. B. terricola ZR2-12 was first selected according to its high rhizosphere competence in sugar beets roots (up to $\log _{10} 10 \mathrm{CFU} \mathrm{g}^{-1}$ RFW) [31], which can now also be confirmed for hops. In this study, the density of S. plymuthica 3Re4-18 in the hop root endorhiza was $\log _{10} 3.0 \pm 0.2 \mathrm{CFU} \mathrm{g} \mathrm{g}^{-1} \mathrm{RFW}$, and the colonization of the rhizosphere was $\log _{10} 2.9 \pm 0.1 \mathrm{CFU} \mathrm{g}{ }^{-1} \mathrm{RFW}$. In $P$. poae RE*1-1-14 treated plants, the bacterial colonization was $\log _{10} 3.0 \pm 0.2 \mathrm{CFU} \mathrm{g}^{-1} \mathrm{RFW}$ in the rhizosphere and $\log _{10} 4.3 \pm 0.2 \mathrm{CFU} \mathrm{g}^{-1} \mathrm{RFW}$ in the endorhiza. Furthermore, S. rhizophila DSM $14405^{\mathrm{T}}$ showed similar abundances of approximately $\log _{10} 3.8 \pm 0.2 \mathrm{CFU} \mathrm{g}{ }^{-1}$ RFW in the rhizosphere and $\log _{10} 4.1 \pm 0.2 \mathrm{CFU} \mathrm{g}^{-1}$ RFW in the endorhiza. In other studies, similar bacterial densities in the rhizosphere of different crops were also found. The strain S. plymuthica 3Re4-18 is described as an effective rhizosphere colonizer [30], and had an average abundance of $\log _{10} 3.6$ to $\log _{10} 4.2 \mathrm{CFU} \mathrm{g}{ }^{-1} \mathrm{RFW}$ in sugar beet depending on the root section [30]. Similarly, the strain S. plymuthica HRO-C48 reached population densities of $\log _{10}$ $3.5 \pm 1.4 \mathrm{CFU} \mathrm{g}^{-1} \mathrm{RFW}$ in oilseed rape [34]. Lower densities of S. plymuthica 3Re4-18 were shown in 
the root system of hops. The abundance of $P$. poae RE*1-1-14 in the rhizosphere of sugar beets ranged from $\log _{10} 3.7$ to $\log _{10} 3.9 \mathrm{CFU} \mathrm{g}^{-1}$ RFW depending on root section [30], and showed superior colonization behavior in the hop rhizosphere. A large variety of life styles and interaction strategies are known for different endophytic bacteria and also rhizosphere bacteria can colonize the endorhiza [35,36]. The endophytic life style of all applied strains emphasizes their intimate plant-microbe interaction and suggests a positive role in hops.

Figure 1. Population densities of B. terricola ZR2-12, P. poae RE*1-1-14, S. plymuthica 3Re4-18, and S. rhizophila DSM14405 ${ }^{\mathrm{T}}$ in the (a) rhizosphere and (b) endorhiza of hops. Mean values followed by different letters are significantly different according to Tukey's test $(P \leq 0.05)$. Error bars indicate standard error.

(a)

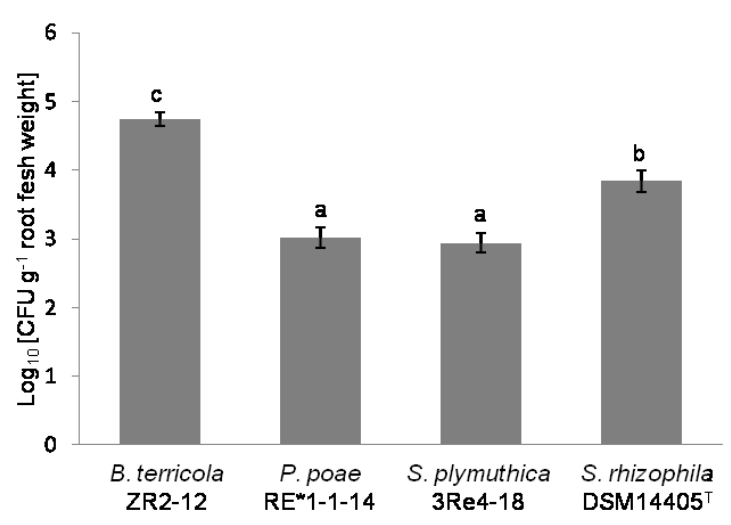

(b)

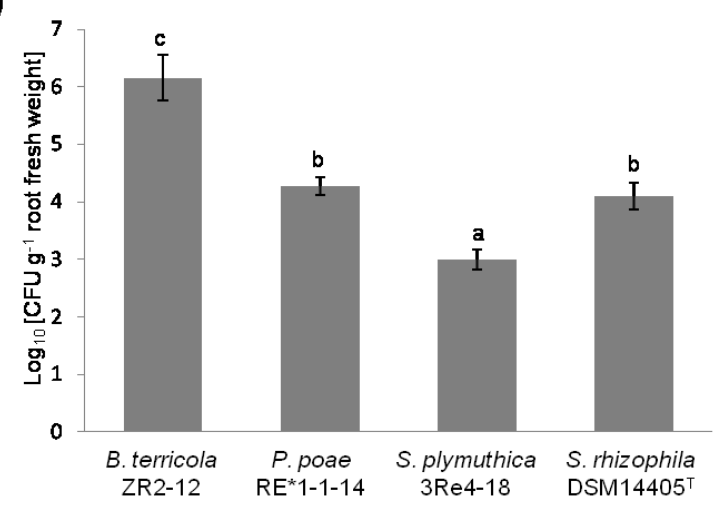

After outdoor hibernation, the plants sprouted under greenhouse conditions. Random samples were analyzed to see if the bacteria could survive at sub-zero temperatures. Again, B. terricola ZR2-12 was the best colonizer with a similar colony density as the colonization experiments above. The other three bacteria were found in the endorhiza with approximately $\log _{10} 3.0 \mathrm{CFU} \mathrm{g}{ }^{-1} \mathrm{RFW}$. These results are important for further biological control measures and practical applications as they will help establish the bacteria in the hops roots.

Furthermore, the potential establishments of these bacteria on seeds were analyzed. Hops seeds were inoculated and the root system cell density was determined after seven weeks. The abundances of B. terricola ZR2-12, S. plymuthica 3Re4-18, and $S$. rhizophila DSM14405 ${ }^{\mathrm{T}}$ ranged from approximately $\log _{10} 3.1$ to $\log _{10} 4.1 \mathrm{CFU} \mathrm{g}{ }^{-1}$ RFW. However, P. poae RE*1-1-14 showed a very low population density.

\subsection{Colonization Patterns Observed by Microscopic Monitoring}

Microscopic analyses were prepared using Confocal Laser Scanning Microscopy (CLSM) to visualize the colonizing behavior in the root system. Exemplarily, the colonization patterns for B. terricola ZR2-12, P. poae RE*1-1-14, and S. plymuthica 3Re4-18 were monitored six to seven days after inoculation. A high density of B. terricola ZR2-12 cells was found in the rhizosphere (Figure 2a), and scattered arrangements were found on root hairs and on the root tip (Figure 2b,c). A scattered colonization was observed in the endorhiza (Figure 2d). Moreover, B. terricola ZR2-12 cells showed a large accumulation of colonies on stem surfaces (Figure 2e). The endophytic P. poae RE*1-1-14 
formed cell colonies along the epidermis cell (Figure 2f) with rod-shaped cells. In addition, P. poae RE*1-1-14 also showed an arrangement of single cells on the root surface with root hairs (Figure $2 \mathrm{~g}$ ) while S. plymuthica 3Re4-18 cells appeared as single cells in small colonies on the surface (Figure 2h,i). Zachow et al. reported similar rhizosphere colonization of $P$. poae RE*1-1-14 and S. plymuthica 3Re4-18 on roots of sugar beets [30]. P. poae RE*1-1-14 formed microcolonies between the epidermis cells, and S. plymuthica 3Re4-18 showed single cells that formed small accumulations between epidermis cells.

Figure 2. Colonization pattern of DsRed-transformed bacteria (red) in the root system of hops six to seven days after inoculation. B. terricola ZR2-12 cells showed (a) a high density on the root surface and appeared in a scattered arrangement (b) on root hairs and (c) on root tip; (d) B. terricola ZR2-12 cells colonized the endorhiza and (e) showed a large accumulation of colonies on the surface of stem; (f) P. poae RE*1-1-14 cells formed colonies along root cells and (g) showed a scattered arrangement on the surface of root hairs; (h-i) S. plymuthica 3Re4-18 cells formed small colonies (arrows).
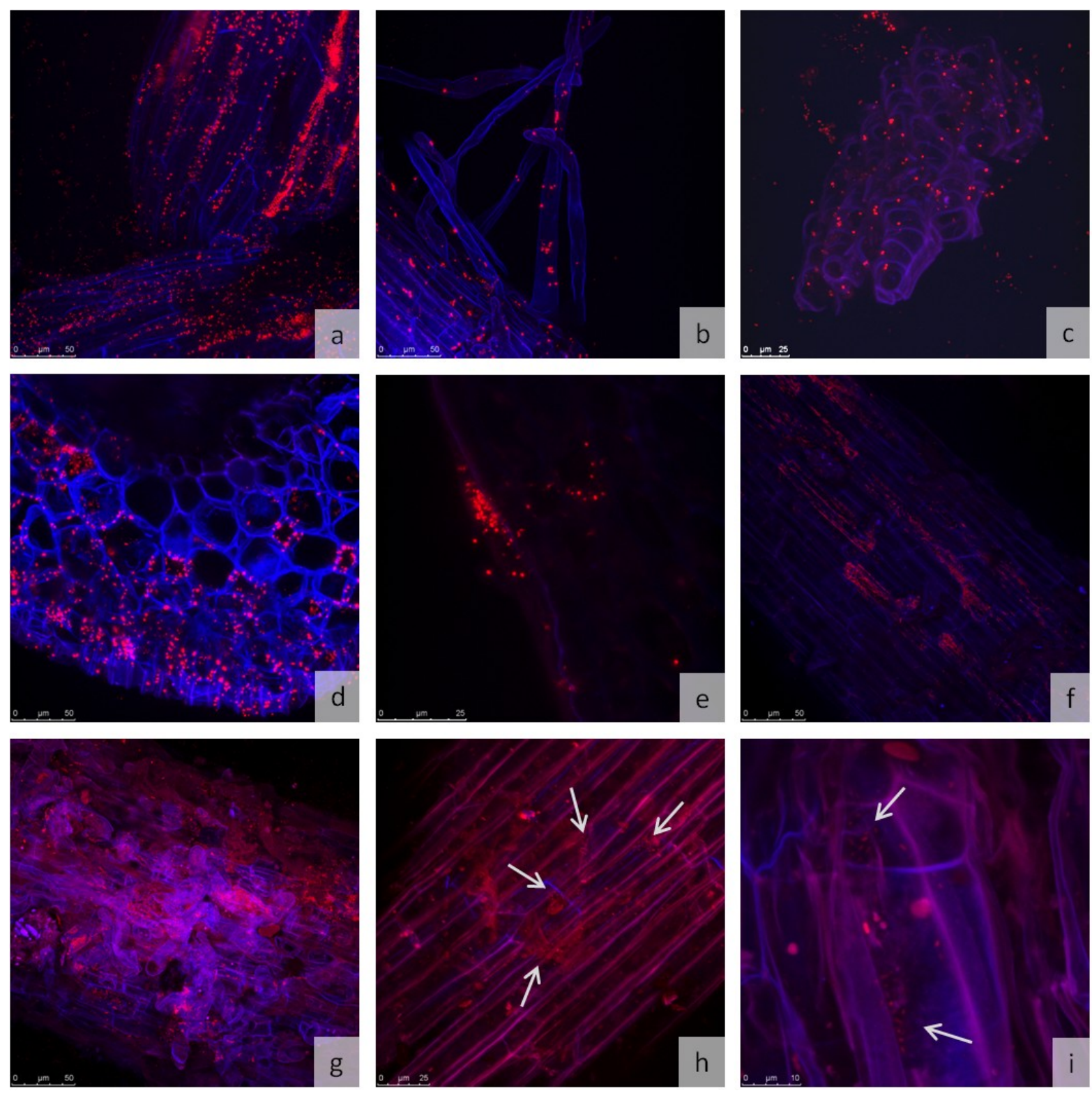


\subsection{Effect of Bacterial Treatment on Plant Growth}

Seeds and plants were dipped in bacterial suspensions to assess the effect of B. terricola ZR2-12, P. poae RE*1-1-14, S. plymuthica 3Re4-18, and S. rhizophila DSM14405 ${ }^{\mathrm{T}}$ treatments on plant growth. Seven weeks after inoculation of the seeds, the length of the plantlets without the roots and the length of the fourth leaves were measured. Additionally, to evaluate an additive effect, seeds were treated with a mixture of $S$. plymuthica 3Re4-18 and S. rhizophila DSM14405 ${ }^{\mathrm{T}}$ (1:1). S. plymuthica 3Re4-18 showed significant PGP effects in both experimental sets (Figure 3), and S. rhizophila DSM14405 ${ }^{\mathrm{T}}$ and the combined strains promote plant growth as shown from the fourth leaves (Figure 3a). However, no significant PGP effects could be observed for plant length (Figure 3b), even though both strains already showed plant growth promotion in other crops $[9,23,29,30]$. In addition, the growth effect on taller cuttings was assessed. The weight gain four weeks after treatment was measured, but no differences in PGP could be found.

Figure 3. Growth promotion effect of $B$. terricola ZR2-12, P. poae RE*1-1-14, S. plymuthica 3Re4-18, S. rhizophila DSM14405 ${ }^{\mathrm{T}}$, and mixed culture of S. plymuthica 3Re4-18 and S. rhizophila DSM14405 ${ }^{\mathrm{T}}$ on hop seedlings assessing (a) the length of the fourth leaves and (b) the length of the plant (without the root). Mean values followed by different letters are significantly different according to Scheffé test $(P \leq 0.05)$. Error bars indicate standard error.

(a)

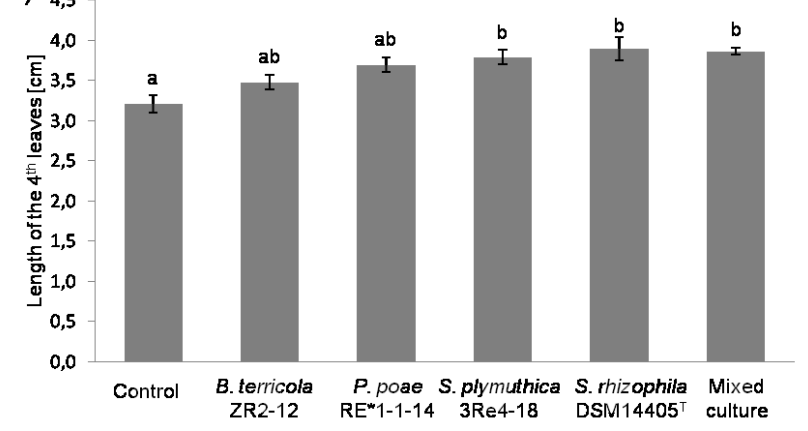

(b) 30

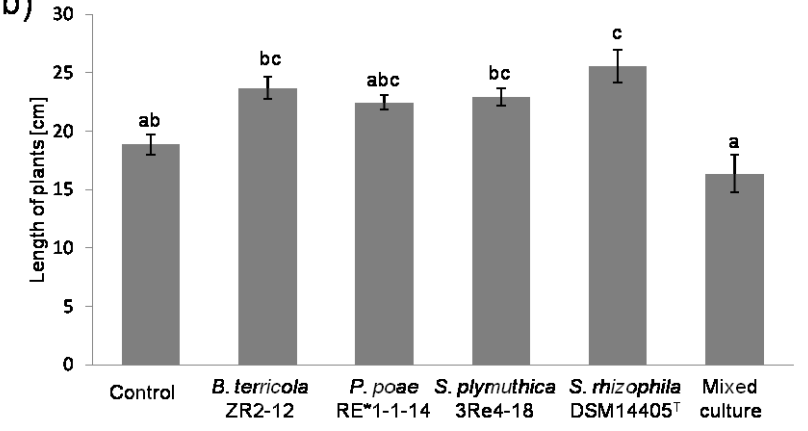

\subsection{In vitro Antagonistic Activity against $V$. nonalfalfae and $V$. dahliae}

The antagonistic activity of the four bacteria against $V$. nonalfalfae and $V$. dahliae was assessed using a dual culture test. The strain $S$. plymuthica 3Re4-18 showed an inhibition zone which has been confirmed with other studies for $V$. dahliae [25,30]. P. poae RE*1-1-14 did not have any antagonistic activity against these two Verticillium species in this or other studies [30]. An inhibition by S. rhizophila DSM14405 ${ }^{\mathrm{T}}$ and B. terricola ZR2-12 could also not be found, although it was described in other studies for $V$. dahliae [21,24]. 


\section{Experimental Section}

\subsection{Hop Cultivars}

The cultivar "Hallertauer Tradition" was used in the experiments due to its wide spread cultivation and its increased susceptibility in fields towards current pathotypes of $V$. nonalfalfae. To assess the PGP effect, seeds of the cross breed of Cascade and 2007/005/504 were treated.

\subsection{Microorganisms}

Four strains of bacteria, previously isolated from diverse microhabitats and crops, were used in this study. For greenhouse-experiments, spontaneous mutated isolates of B. terricola ZR2-12, P. poae RE*1-1-14, S. plymuthica 3Re4-18, and $S$. rhizophila DSM14405 ${ }^{\mathrm{T}}$ resistant to rifampicin (100 $\mu \mathrm{g} \mathrm{mL}^{-1}$; Roth, Karlsruhe, Germany) were used. No differences in growth parameters (colony morphology and growth rate) and traits (antifungal properties towards $V$. nonalfalfae and $V$. dahliae, proteolytic activity, Box PCR pattern) were found between the mutant and wild type. The strains were stored in nutrient broth ( $10 \mathrm{~g}$ of peptone, $5 \mathrm{~g}$ of yeast extract, Roth and $5 \mathrm{~g}$ of $\mathrm{NaCl}$, Merck, Darmstadt, Germany in $1 \mathrm{~L}$ of distilled water, $\mathrm{pH} 7$ ) containing $12.5 \%$ glycerol at $-80{ }^{\circ} \mathrm{C}$. The wildtype strains were maintained in the Strain Collection of Antagonistic Microorganisms (SCAM) at Graz University of Technology in LB medium containing $15 \%$ glycerol at $-70{ }^{\circ} \mathrm{C}$. The used $V$. nonalfalfae and $V$. dahliae strains for dual culture tests were isolated from infected hop bines. The fungi were maintained as monospore cultures on prune agar at $20^{\circ} \mathrm{C}$ [37], and the species identity was verified by specific primers $[38,39]$.

\subsection{Determination of Root Colonization}

Bacterial overnight culture $(12 \mathrm{~mL})$ in nutrient broth $\left(100 \mathrm{~mL}\right.$ containing $100 \mu \mathrm{g} \mathrm{mL} \mathrm{m}^{-1}$ of rifampicin, $\left.28^{\circ} \mathrm{C}, 120 \mathrm{rpm}\right)$ was transferred to $500 \mathrm{~mL}$ of a new culture $\left(28{ }^{\circ} \mathrm{C}, 120 \mathrm{rpm}\right)$ and diluted with $0.85 \% \mathrm{NaCl}$ solution to a final cell concentration of $10^{8} \mathrm{CFU} \mathrm{mL}^{-1}$. Roots of the cultivar "Hallertauer Tradition" were dipped in the bacterial suspension for $15 \mathrm{~min}$ and planted in unsterilized soil (Lorenzer potting soil, Einheitserde special, Einheitserdewerke Patzer, Sinntal-Jossa, Germany). Control plants were dipped in $0.85 \% \mathrm{NaCl}$ solution. The experiment was done in twelve replicates for each bacterium as well as for the negative control and repeated three times under greenhouse conditions with minimum of $13 \mathrm{~h}$ light (artificial light between 6 am and $7 \mathrm{pm}$, if the daylight is under 40 kLux) with a minimum temperature of $22{ }^{\circ} \mathrm{C}$ at day and $19{ }^{\circ} \mathrm{C}$ at night. After four weeks, twelve plants were divided into four parts (containing three plants) for each BCA. $2.5 \mathrm{~g}$ of roots (soil adhering to roots) were incubated in $15 \mathrm{~mL}$ of $0.85 \% \mathrm{NaCl}$ solution for $20 \mathrm{~min}$ and at $300 \mathrm{rpm}$ to determine bacterial density in the rhizosphere. To define the colonization number in the endorhiza, $2 \mathrm{~g}$ of roots were cleaned, surface sterilized with sodium hypochlorite ( $3 \%$ active chlorine, $5 \mathrm{~min}$ ) and washed three times with sterile water. For sterilization control, roots were dipped on a nutrient agar (nutrient broth added $15 \mathrm{~g} \mathrm{~L}^{-1}$ agar agar, Roth) containing rifampicin (100 $\mu \mathrm{g} \mathrm{mL}^{-1}$; Roth) and nystatin (20 $\mu \mathrm{g} \mathrm{mL}^{-1}$; Roth). The roots were then crushed with $5 \mathrm{~mL} 0.85 \% \mathrm{NaCl}$ solution by mortar and pestle. The resulting suspensions of the rhizosphere and endorhiza were serial diluted, and $100 \mu \mathrm{L}$ 
were plated on selective nutrient agar as described above. After seven days of incubation $\left(28{ }^{\circ} \mathrm{C}\right.$, in dark), the number of colonies (CFU $\mathrm{g}^{-1}$ fresh root weight) was determined. After the outdoor hibernation in sub-zero temperatures, six random samples of the roots, which were divided into two parts, were taken and re-isolated as described above.

\subsection{Confocal Laser Scanning Microscopy (CLSM)}

For microscopy analysis, DsRed-labeled strains of B. terricola ZR2-12, P. poae RE*1-1-14, and $S$. plymuthica 3Re4-18 were stored at $-70{ }^{\circ} \mathrm{C}$ in nutrient broth (Luria Bertani LB, Roth) amended with $15 \%$ glycerol and subsequently employed [30,31]. The roots of seven weeks old cuttings were washed with tap water and dipped in an overnight culture of bacteria $\left(30^{\circ} \mathrm{C}\right.$; Luria Bertani LB supplemented with $40 \mu \mathrm{g} \mathrm{mL} \mathrm{m}^{-1}$ tetracycline; Roth) for P. poae RE*1-1-14 and S. plymuthica 3Re4-18, and B. terricola ZR2-12 with $100 \mu \mathrm{g} \mathrm{mL} \mathrm{mL}^{-1}$ trimethoprim (Sigma Aldrich, St. Louis, MO, USA) for $30 \mathrm{~min}$. They were planted in sterilized standard potting compost (Gramoflor, Profi-Substrat, Topfpikier $\mathrm{M}+\mathrm{Ton}+\mathrm{Fe}$, Vechta, Austria) and closed with a lid. One week after incubation (14 h artificial light at $25{ }^{\circ} \mathrm{C}$ and $70 \%$ air moisture; $10 \mathrm{~h}$ darkness at $18{ }^{\circ} \mathrm{C}$ and $70 \%$ air moisture), the root system was observed with a TCS SPE confocal microscopy (Leica Microsystems, Germany) using the following modulations for laser lines $(\mathrm{nm}) /$ detection wavelengths $(\mathrm{nm})$ : DsRed, 532/570-620 and plant tissues (autofluorescence), 405/430-500. The rhizosphere and endorhiza of randomly selected roots were analyzed. Because of the high abundance of B. terricola ZR2-12 in the rhizophere and endorhiza, the stem were observed in details.

\subsection{Plant Growth Promotion (PGP) in the Greenhouse}

The weight of the plants before and four weeks after the bacterial treatment was measured to determine the PGP. The same dipping procedure for the determination of cell densities was used. In addition, seeds of the cross breed of Cascade and 2007/005/504 were dipped for 15 min in bacterial

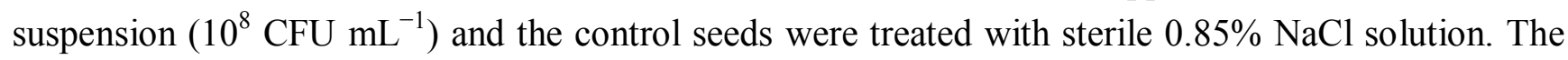
seeds were planted in potting compost (Lorenzer potting soil) and grew for seven weeks. The growth was determined by the size of the plantlets without the roots and the fourth leaves (including the cotyledons). The roots were assembled and separated into two parts of $1.5 \mathrm{~g}$ to $2 \mathrm{~g}$ to control successful root colonization. The roots were then ground with $15 \mathrm{~mL} 0.85 \% \mathrm{NaCl}$ with mortar and pestle and $100 \mu \mathrm{L}$ plated on nutrient agar (nutrient broth added $15 \mathrm{~g} \mathrm{~L}^{-1}$ agar agar, Roth) containing rifampicin $\left(100 \mu \mathrm{g} \mathrm{mL}^{-1}\right.$, Roth) and nystatin $\left(20 \mu \mathrm{g} \mathrm{mL}^{-1}\right.$; Roth). After seven days, the colonization was determined. The growth experiments were done in twenty replicates and independently repeated two times.

\subsection{Screening for Antagonistic Activity}

The in vitro antagonism was determined in a dual culture assay. $200 \mu \mathrm{L}$ of seven day old mycelia suspension $V$. nonalfalfae isolated from infected hops was plated onto PDA (potato extract glucose agar; Roth) and Waksman agar containing $5 \mathrm{~g}$ tryptone/peptone ex casein (Roth), $10 \mathrm{~g}$ glucose (Roth), $3 \mathrm{~g}$ yeast extract (Roth), $20 \mathrm{~g}$ agar (Roth) and filled up to $1 \mathrm{~L}$ with distilled water. After $30 \mathrm{~min}$, the 
bacteria were spotted on the plate. Antagonistic activity and the inhibition zone were assessed after seven days of incubation at $20^{\circ} \mathrm{C}$.

\subsection{Statistical Analysis}

Root colonization data was $\log _{10}$ transformed before statistical analysis, and the package SPSS (SPSS Inc., Chicago, IL, USA) was used for statistical data analysis. For the determination of PGP, the significance towards the control plants was analyzed using the Scheffé's test and Tukey's test $(P \leq 0.05)$. The outlier test DIXON was used in the PGP experiments and the outliers were excluded from the statistical analysis. The deviation was indicated as standard error.

\section{Conclusions}

This study investigates the preliminary requirements of four bacteria, B. terricola ZR2-12, P. poae RE*1-1-14, S. plymuthica 3Re4-18, and S. rhizophila DSM14405 ${ }^{\mathrm{T}}$ to act as BCAs to suppress Verticillium wilt in hops. Many previous studies have already demonstrated the ability of the four bacteria for biological control in other crops. Regarding their rhizosphere competence and PGP effect, S. plymuthica 3Re4-18 and S. rhizophila DSM14405 ${ }^{\mathrm{T}}$ are promising candidates for BCA on hops, as well as B. terricola ZR2-12 that showed exceptionally high cell densities. Due to this rhizosphere competence even after hibernation in sub-zero temperatures, this strain can be a suitable BCA in hops. The bacterial treatment of seeds with S. plymuthica 3Re4-18 and S. rhizophila DSM14405 ${ }^{\mathrm{T}}$ was also shown to benefit plant growth. Antagonistic activity against $V$. dahliae is known for $B$. terricola ZR2-12, S. plymuthica 3Re4-18, and S. rhizophila DSM14405 ${ }^{\mathrm{T}}$ and an antagonistic effect has also been shown via dual culture test in this study for $S$. plymuthica 3Re4-18 against $V$. nonalfalfae and $V$. dahliae. Furthermore, the beneficial traits of $S$. plymuthica 3Re4-18 are well-known and contribute to its biotechnological potential in hops. Nevertheless, to objectively assess the ability of these beneficial bacteria strains towards $V$. nonalfalfae in hops, artificial infection tests and further experiments under field condition are necessary, also to assess the effects on crop yield. Furthermore, the consistent efficacy of these beneficial bacteria must be verified in the field.

\section{Acknowledgments}

This project was funded by the Erzeugergemeinschaft Hopfen HVG e. G. and the Wissenschaftsförderung der deutschen Brauwirtschaft (Wifö). We would like to thank Henry Müller and Anastasia Bragina (Graz, Austria) for their help with the microscopic analysis. The authors thank Sebastjan Radišek (Žalec, Slovenia) for his very valuable advice. We are also grateful to Meg Starcher (Graz, Austria) for English revision.

\section{Conflicts of Interest}

The authors declare no conflict of interest. 


\section{References}

1. Engelhard, A.W. Host index of Verticillium albo-atrum (including Verticillium dahliae Kleb.). Plant Dis. Rep. Suppl. 1957, 244, 23-49.

2. Harris, R.V. A wilt disease of hops. East Malling Res. Stn. Annu. Rep. 1925 1927, Suppl. II, 92-93.

3. Inderbitzin, P.; Bostock, R.M.; Davis, R.M.; Usami, T.; Platt, H.W.; Subbarao, K.V. Phylogenetics and taxonomy of the fungal vascular wilt pathogen Verticillium, with the descriptions of five new species. PLoS One 2011, 6, e28341.

4. Neve, R.A. Hops; Chapman \& Hall: London, UK, 1991.

5. Keyworth, W.G. Verticillium wilt of the hop (Humulus lupuls). Ann. Appl. Biol. 1942, 29, 346-357.

6. Debode, J.; De Maeyer, K.; Perneel, M.; Pannecoucque, J.; De Backer, G.; Höfte, M. Biosurfactants are involved in the biological control of Verticillium microsclerotia by Pseudomonas spp. J. Appl. Microbiol. 2007, 103, 1184-1196.

7. Müller, H.; Westendorf, C.; Leitner, E.; Chernin, L.; Riedel, K.; Schmidt, S.; Eberl, L.; Berg, G. Quorum-sensing effects in the antagonistic rhizosphere bacterium Serratia plymuthica HRO-C48. FEMS Microbiol. Ecol. 2009, 67, 468-478.

8. Prieto, P.; Navarro-Raya, C.; Valverde-Corredor, A.; Amyotte, S.G.; Dobinson, K.F.; Mercado-Blanco, J. Colonization process of olive tissues by Verticillium dahliae and its in planta interaction with the biocontrol root endophyte Pseudomonas fluorescens PICF7. Microb. Biotechnol. 2009, 2, 499-511.

9. Berg, G. Plant-microbe interactions promoting plant growth and health: perspectives for controlled use of microorganisms in agriculture. Appl. Microbiol. Biotechnol. 2009, 84, 11-18.

10. Compant, S.; Duffy, B.; Nowak, J.; Clement, C.; Barka, E.A. Use of plant growth-promoting bacteria for biocontrol of plant diseases: Principles, mechanisms of action, and future prospects. Appl. Environ. Microbiol. 2005, 71, 4951-4959.

11. Compant, S.; Clément, C.; Sessitsch, A. Plant growth-promoting bacteria in the rhizo- and endosphere of plants: Their role, colonization, mechanisms involved and prospects for utilization. Soil Biol. Biochem. 2010, 42, 669-678.

12. Lugtenberg, B.; Kamilova, F. Plant-growth-promoting rhizobacteria. Ann. Rev. Microbiol. 2009, 63, 541-556.

13. Weller, D.M. Biological control of soilborne plant pathogens in the rhizosphere with bacteria. Ann. Rev. Phytopathol. 1988, 26, 379-407.

14. Erdogan, O.; Benlioglu, K. Biological control of Verticillium wilt on cotton by the use of fluorescent Pseudomonas spp. under field conditions. Biol. Control 2010, 53, 39-45.

15. Kurze, S.; Bahl, H.; Dahl, R.; Berg, G. Biological control of fungal strawberry diseases by Serratia plymuthica HRO-C48. Plant Dis. 2001, 85, 529-534.

16. Mercado-Blanco, J.; Rodríguez-Jurado, D.; Hervás, A.; Jiménez-Díaz, R.M. Suppression of Verticillium wilt in olive planting stocks by root-associated fluorescent Pseudomonas spp. Biol. Control 2004, 30, 474-486. 
17. Müller, H.; Berg, G. Impact of formulation procedures on the effect of the biocontrol agent Serratia plymuthica HRO-C48 on Verticillium wilt in oilseed rape. BioControl 2008, 53, 905-916.

18. Naraghi, L.; Heydari, A.; Rezaee, S.; Razavi, M.; Afshari-Azad, H. Biological control of Verticillium wilt of greenhouse cucumber by Talaromyces flavus. Phytopathol. Mediterr. 2010, 49, 321-329.

19. Naraghi, L.; Heydari, A.; Rezaee, S.; Razavi, M.; Jahanifar, H. Study on antagonistic effects of Talaromyces flavus on Verticillium albo-atrum, the causal agent of potato wilt disease. Crop Prot. 2010, 29, 658-662.

20. Naraghi, L.; Heydari, A.; Rezaee, S.; Razavi, M.; Jahanifar, H.; Khaledi, E. Biological control of tomato Verticillium wilt disease by Talaromyces Flavus. J. Plant Prot. Res. 2010, 50, 360-365.

21. Gasser, I.; Müller, H.; Berg, G. Ecology and characterization of polyhydroxyalkanoate-producing microorganisms on and in plants. FEMS Microbiol. Ecol. 2009, 70, 142-150.

22. Zachow, C.; Tilcher, R.; Berg, G. Sugar beet-associated bacterial and fungal communities show a high indigenous antagonistic potential against plant pathogens. Microb. Ecol. 2008, 55, 119-129.

23. Faltin, F.; Lottmann, J.; Grosch, R.; Berg, G. Strategy to select and assess antagonistic bacteria for biological control of Rhizoctonia solani Kühn. Can. J. Microbiol. 2004, 50, 811-820.

24. Minkwitz, A.; Berg, G. Comparison of antifungal activities and 16S ribosomal DNA sequences of clinical and environmental isolates of Stenotrophomonas maltophilia. J. Clin. Microbiol. 2001, 39, 139-145.

25. Berg, G.; Krechel, A.; Ditz, M.; Sikora, R.A.; Ulrich, A.; Hallmann, J. Endophytic and ectophytic potato-associated bacterial communities differ in structure and antagonistic function against plant pathogenic fungi. FEMS Microbiol. Ecol. 2005, 51, 215-229.

26. Grosch, R.; Dealtry, S.; Schreiter, S.; Berg, G.; Mendonça-Hagler, L.; Smalla, K. Biocontrol of Rhizoctonia solani: complex interaction of biocontrol strains, pathogen and indigenous microbial community in the rhizosphere of lettuce shown by molecular methods. Plant Soil 2012, 361, 343-357.

27. Grosch, R.; Faltin, F.; Lottmann, J.; Kofoet, A.; Berg, G. Effectiveness of 3 antagonistic bacterial isolates to control Rhizoctonia solani Kühn on lettuce and potato. Can. J. Microbiol. 2005, 51, $345-353$.

28. Scherwinski, K.; Grosch, R.; Berg, G. Effect of bacterial antagonists on lettuce: active biocontrol of Rhizoctonia solani and negligible, short-term effects on nontarget microorganisms. FEMS Microbiol. Ecol. 2008, 64, 106-116.

29. Schmidt, C.S.; Alavi, M.; Cardinale, M.; Müller, H.; Berg, G. Stenotrophomonas rhizophila DSM $14405^{\mathrm{T}}$ promotes plant growth probably by altering fungal communities in the rhizosphere. Biol. Fertil. Soils 2012, 48, 947-960.

30. Zachow, C.; Fatehi, J.; Cardinale, M.; Tilcher, R.; Berg, G. Strain-specific colonization pattern of Rhizoctonia antagonists in the root system of sugar beet. FEMS Microbiol. Ecol. 2010, 74, 124-135.

31. Gasser, I.; Cardinale, M.; Müller, H.; Heller, S.; Eberl, L.; Lindenkamp, N.; Kaddor, C.; Steinbüchel, A.; Berg, G. Analysis of the endophytic lifestyle and plant growth promotion of Burkholderia terricola ZR2-12. Plant Soil 2011, 347, 125-136. 
32. Berg, G.; Müller, H.; Zachow, C.; Opelt, K.; Scherwinski, K.; Tilcher, R.; Ulrich, A.; Hallmann, J.; Grosch, R.; Sessitsch, A. Enodphytes: Structural and functional diversity and biotechnological applications in control of plant pathogens. Russ. J. Genet. Appl. Res. 2008, 6, 16-25.

33. Egamberdieva, D.; Kucharova, Z.; Davranov, K.; Berg, G.; Makarova, N.; Azarova, T.; Chebotar, V.; Tikhonovich, I.; Kamilova, F.; Validov, S.Z.; Lugtenberg, B. Bacteria able to control foot and root rot and to promote growth of cucumber in salinated soils. Biol. Fert. Soils 2011, 47, 197-205.

34. Abuamsha, R.; Salman, M.; Ehlers, R.U. Differential resistance of oilseed rape cultivars (Brassica napus ssp. oleifera) to Verticillium longisporum infection is affected by rhizosphere colonisation with antagonistic bacteria, Serratia plymuthica and Pseudomonas chlororaphis. BioControl 2011, 56, 101-112.

35. Hardoim, P.R.; van Overbeek, L.S.; van Elsas, J.D. Properties of bacterial endophytes and their proposed role in plant growth. Trends Microbiol. 2008, 16, 463-471.

36. Mitter, B.; Petric, A.; Shin, M.W.; Hauberg-Lotte, L.; Reinhold-Hurek, B.; Nowak, J.; Sessitsch, A. Comparative genome analysis of Burkholderia phytofirmans PsJN reveals a wide spectrum of endophytic lifestyles based on interaction strategies with host plants. Front. Plant Sci. 2013, 4, doi:10.3389/fpls.2013.00120.

37. Talboys, P.W. A culture-medium aiding the identification of Verticillium albo-atrum and V. dahliae. Plant Pathol. 1960, 9, 57-58.

38. Carder, J.H.; Morton, A.; Tabrett, A.M.; Barbara, D.J. Detection and differentiation by PCR of subspecific groups within two Verticillium species causing vascular wilts in herbaceous hosts. In Modern Assays for Plant Pathogenic Fungi: Indification, Detection and Quantification; Schots, A., Dewey, F.M., Oliver, R., Eds.; CAB International: Oxford, UK, 1994; pp. 91-97.

39. Down, G.; Barbara, D.; Radišek, S. Verticillium albo-atrum and V. dahliae on hop. Bull. OEPP 2007, 37, 528-535.

(C) 2013 by the authors; licensee MDPI, Basel, Switzerland. This article is an open access article distributed under the terms and conditions of the Creative Commons Attribution license (http://creativecommons.org/licenses/by/3.0/). 